\title{
The Nutritional Status of Young Pregnant Women and the Health of Newborns Affects the Growth of Children 6-24 Months in Kupang
}

\author{
Yeri D. Nenogasu ${ }^{1 *}$, Stefanus P. Manongga ${ }^{2}$, Christina O. Lada ${ }^{2}$, Herianus J. D Lalel ${ }^{3}$, Frans Umbu Data ${ }^{3}$ \\ ${ }^{1}$ Public Health Sciences Students, Post-Graduate Program, Nusa Cendana University, Kupang-85001, East Nusa Tenggara, Indonesia \\ ${ }^{2}$ Public Health Sciences Lecturer, Post-Graduate Program, Nusa Cendana University, Kupang-85001, East Nusa Tenggara, Indonesia \\ ${ }^{3}$ Professor at Nusa Cendana University, Kupang-85001, East Nusa Tenggara, Indonesia
}

\section{Article History}

Received: 02.12.2020

Accepted: 14.12.2020

Published: 20.12.2020

Journal homepage:

https://www.easpublisher.com

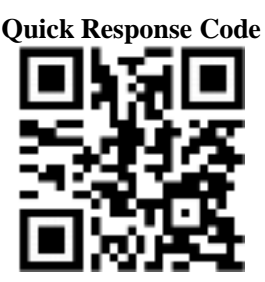

Abstract: Introduction: Pregnancy at an early age causes nutritional competition between mother and fetus, which has a negative impact on the health of the mother and fetus, and inhibits growth in infancy. The purpose of this study was to determine the effect of nutritional status of young pregnant women and the health of newborns on the growth of children aged 6-24 months. Material and Methods: A sample of 100 mothers and children based on inclusion criteria. Primary and secondary data collection was carried out from April to June 2020 after obtaining ethical permission. The analysis method uses Partial Least Square with the smart PLS 3.0 application. Result: The R2 values generated for the variables of child growth and newborn health were 0.074 and 0.055 . The nutritional status of pregnant women at early age significantly affects the health of newborns (T-statistic above the rule of thumb, namely 3.024). Furthermore, the health of the newborn significantly affects the growth of the child (the T-statistic is above the rule of thumb, namely 2.136). The nutritional status of pregnant women at early age had an impact but did not significantly affect the growth of the child (T-statistic under the rule of thumb, namely 0.124). Conclusion: Prevention of pregnancy at an early age is important because it affects the growth of children aged 6-24 months and is a risk factor for growth problems from generation to generation.

Keywords: Child Growth, Pregnancy at an early age.

Copyright (C) 2020 The Author(s): This is an open-access article distributed under the terms of the Creative Commons Attribution 4.0 International License (CC BY-NC 4.0) which permits unrestricted use, distribution, and reproduction in any medium for non-commercial use provided the original author and source are credited.

\section{INTRODUCTION}

Pregnancy at an early age is a serious public health problem because it affects the health of mothers and children [1]. It has a negative impact on the health of mothers and babies, but $58.8 \%$ of pregnancies occurred in adolescence, out of $93.3 \%$ of women aged $10-54$ years who have been pregnant (including those who are pregnant) in Indonesia [2]. In 2018 there were $4.8 \%$ pregnancies among adolescents in Kupang [3].

In Indonesia, complications that occur in pregnant women at a young age during pregnancy are chronic energy deficiency of $33.5 \%$ at $15-19$ years of age, anemia of $84.6 \%$ at $15-24$ years of age, swelling of the legs accompanied by seizures of $12,4 \%$ at $10-14$ years of age. Labor complications such as premature rupture of membranes was $22.9 \%$ and prolonged labor was $10.2 \%$ at the age of less than 15 years. Complications during childbirth such as bleeding by $3.4 \%$ and baby blues by $2.2 \%$ occurred at the age of 10 14 years. The complications mentioned above are higher than that of pregnant, childbirth and postpartum women at the age of more than 20 years [2].
Intra-uterine and extra-uterine factors affect the growth of children 6-24 months. Pregnancy at an early age causes the mother to experience malnutrition and anemia which affects fetal growth during pregnancy [1]. Maternal nutrition during pregnancy is a risk factor for growth problems (stunting) in children [4]. There is nutritional competition between mother and fetus because in this phase it still occurs growth in the mother, resulting in increased maternal weight during pregnancy and can be accompanied by anemia due to nutritional deficiencies [5].

The effects caused by pregnancy at an early age are very complex and can affect the health of both mother and child. Therefore, this study aims to examine the effect of early pregnancy with a focus on the nutritional status of young pregnant women and the health of newborns on child growth.

\section{METHODS}

This type of research is a correlational analytic study with a cross sectional approach. This study is focused on examining the effect of nutritional status of young pregnant women and the health of newborns on 
the growth of children aged 6-24 months. The correctness of the theory concept formulated is tested using Structural Equation Modeling (SEM) with the Partial Least Square (PLS) approach with the help of the Smart PLS version 3.0 application. The research was carried out in the Kupang area from April to June 2020 after obtaining ethical permission by the Health Research Ethics Commission of Nusa Cendana University. The population in this study were pregnant women at early age ( $<20$ years). A sample of 100 respondents with conditions in the form of maternal age at pregnancy and childbirth $<20$ years, having 1 child, having children aged 6-24 months, and living in the same house with the child. Mothers with a history of cardiovascular disorders before pregnancy, a history of diabetes and chronic hypertension, a history of multiple pregnancies, and children who have body deformities were not included. This study is focused on analyzing the influence of the latent variables formed in the model of factors associated with child growth caused by pregnancy at an early age. The latent variable in question is the history of the mother's nutritional status, the health of the newborn and the growth of the child. Each latent construct has several measures or indicators which are described as follows:

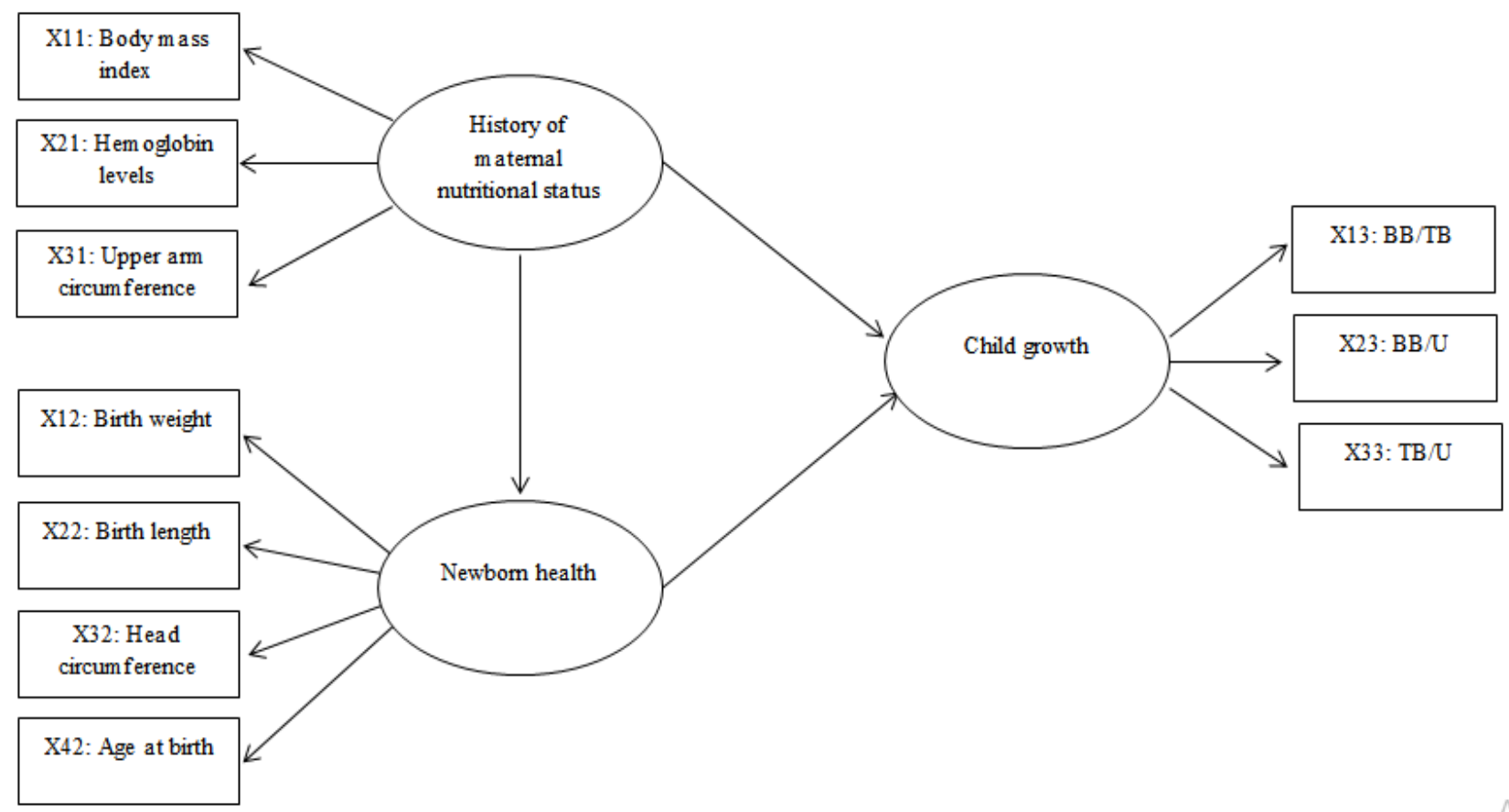

Fig-1: Model of factors that influence child growth

\section{RESULTS}

\section{Evaluate the Outer Model}

The measurement model using reflective indicators is carried out by evaluating the convergent validity and discriminant validity which is assessed based on the loading factor $(>0.5)$. The loading factor value used is $>0.5$ by considering the opinion of the expert on the $\mathrm{BB} / \mathrm{TB}$ indicator, where these indicators are important in assessing children's growth. Indicators must be eliminated (eliminated) if the loading factor value is $<0.5$. Furthermore, evaluating the value of Average Variance Extracted $(>0.5)$, cross loading $(>0.7)$ and composite reliability $(>0.7)[6,14]$. The analysis shows that the indicators X21, X32 and X42 must be eliminated. The results of running PLS are shown in the following figure: 


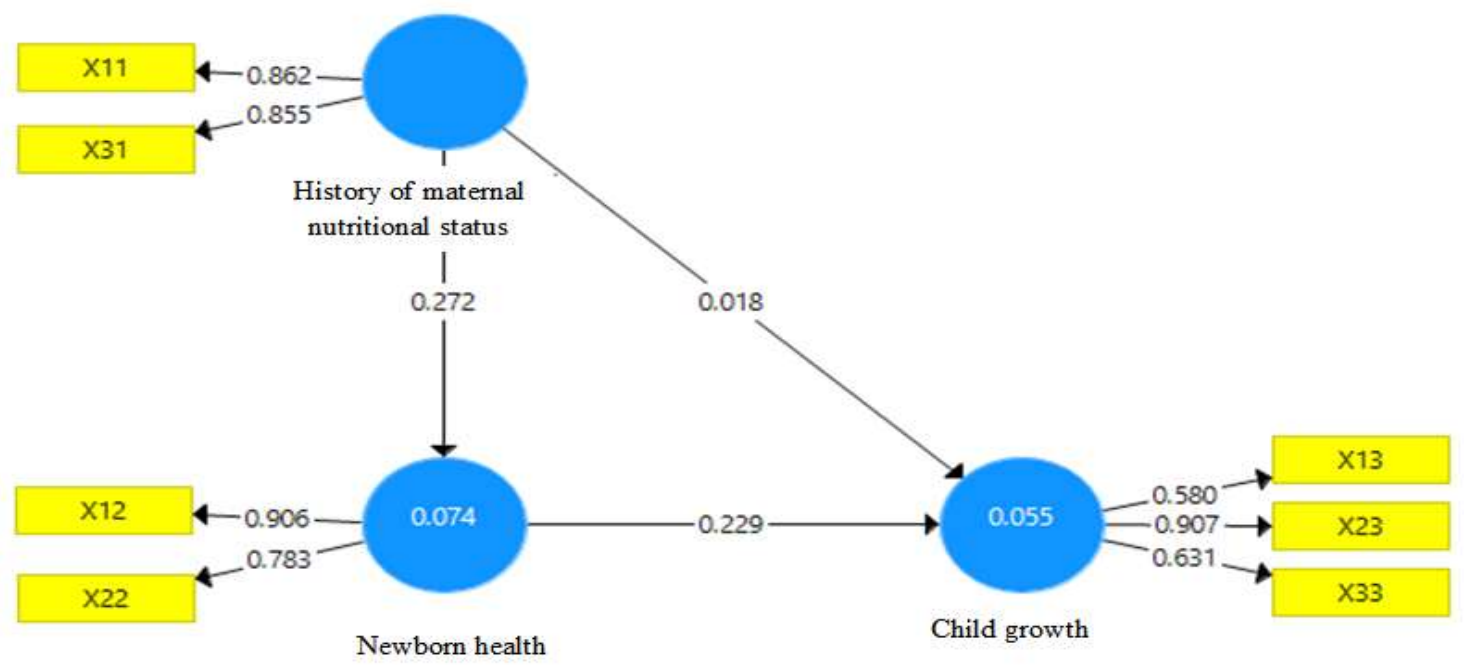

Fig-2: Path diagram with loading factor value

Based on the loading factor, the AVE value and composite reliability are presented in the following table:

Table-1: AVE value and Composite reliability

\begin{tabular}{|l|l|l|l|}
\hline Construct & AVE & Composite reliability & Description \\
\hline History of maternal nutritional status & 0,737 & 0,849 & Qualify \\
\hline Newborn health & 0,717 & 0,834 & Qualify \\
\hline Child growth & 0,519 & 0,757 & Qualify \\
\hline
\end{tabular}

Furthermore, the resulting cross loading value is as follows:

Table-2: Value of cross loading

\begin{tabular}{|l|l|l|l|}
\hline Indicator & History of maternal nutritional status & Newborn health & Child growth \\
\hline $\mathrm{X} 11$ & 0,862 & 0,234 & 0,077 \\
\hline $\mathrm{X} 31$ & 0,855 & 0,233 & 0,061 \\
\hline $\mathrm{X} 12$ & 0,236 & 0.906 & 0,235 \\
\hline $\mathrm{X} 22$ & 0,188 & 0,783 & 0,150 \\
\hline $\mathrm{X} 13$ & 0,022 & 0,172 & 0,580 \\
\hline $\mathrm{X} 23$ & 0,143 & 0,207 & 0,907 \\
\hline X33 & $-0,025$ & 0,161 & 0,631 \\
\hline
\end{tabular}

Based on the loading factor value, AVE, composite reliability and cross loading, the convergent validity and discriminant validity tests evaluated in the outer model can be concluded to be valid and reliable.

\section{Inner Model Evaluation}

Inner model in PLS is evaluated with R2 value for dependent constructs and path coefficients or t- values for each path for significant test between constructs in the inner model. The resulting $\mathrm{R} 2$ value (R2: 0.074) shows that the nutritional status of the mother has a positive effect $(7.4 \%)$ on the health of newborns and the health of newborns has a positive effect $(5.5 \%)$ on children's growth (R2: 0.055). Furthermore, the path coefficients and T-statistic values for each path are presented in the following table:

Table-3: Path coefficients on inner model testing

\begin{tabular}{|l|l|l|l|l|l|}
\hline Construct & $\begin{array}{l}\text { Original } \\
\text { Sample }\end{array}$ & $\begin{array}{l}\text { Sample } \\
\text { Mean }\end{array}$ & $\begin{array}{l}\text { Standard } \\
\text { Deviation }\end{array}$ & $\begin{array}{l}\text { T- } \\
\text { statistic }\end{array}$ & Description \\
\hline $\begin{array}{l}\text { History of maternal nutritional status } \\
->\text { newborn health }\end{array}$ & 0,272 & 0,291 & 0,106 & 3,024 & Significant \\
\hline Newborn health -> child growth & 0,229 & 0,260 & 0,120 & 2,136 & Significant \\
\hline $\begin{array}{l}\text { History of maternal nutritional status } \\
->\text { child growth }\end{array}$ & 0,018 & 0,010 & 0,148 & 0,124 & $\begin{array}{l}\text { Not } \\
\text { significant }\end{array}$ \\
\hline
\end{tabular}

*Significant level 5\% 
The complete inner model and influence weight values between latent variables, both directly and indirectly, are presented in the following figure:

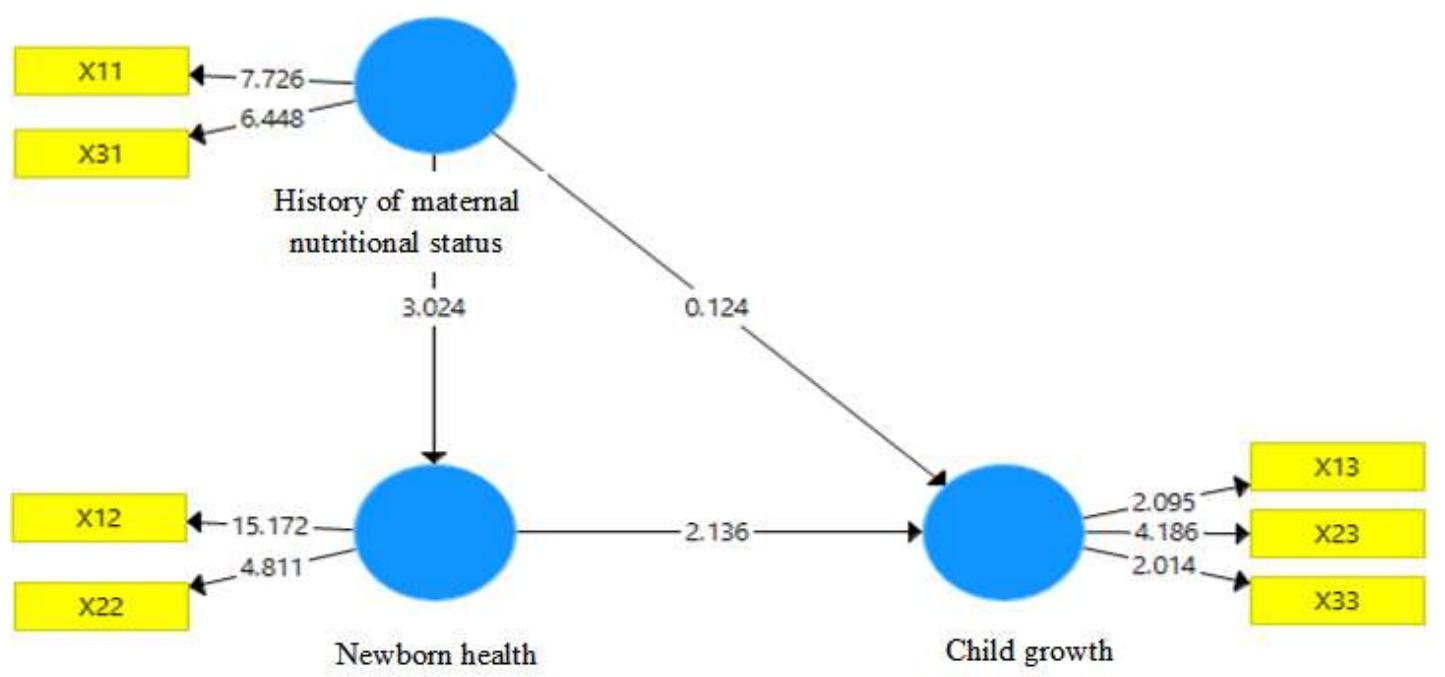

Fig-3: Inner model based on smart PLS output

\section{DISCUSSION}

The path coefficient test results showed that the variable nutritional status history of young pregnant women significantly affects the health of newborns based on the T-statistic value above the rule of thumb (> 1.96), namely 3.024. Nutritional status in this study that meets the outer model standards, namely the index of maternal body mass as seen based on the mother's weight at the beginning of pregnancy $(<1$ st trimester) and hemoglobin levels during pregnancy are important in supporting optimal fetal growth. This is relevant to the study of Goli et al., where the pregnancy at an early age significantly affects the body mass index and hemoglobin levels in mothers [1]. Maternal body mass index has a positive effect on birth weight and subsequent weight gain in children [7]. Furthermore, explained by Workicho et al., the nutritional and biological losses are higher in young pregnant women and can interfere with fetal growth and development [8]. Chen et al., reported a significant association between pregnancy at an early age with birth weight, birth length and head circumference of babies from birth to 18 months of age [9]. Other results are supported by Prakash et al., where pregnancy at an early age has an impact on women's reproductive health and has an impact on growth failure based on anthropometry of children aged $0-5$ years [10].

The significant effect caused by the nutritional status of pregnant women at early age is due to linear growth that generally only completes at the age of 1618 years and is followed by the maturation of the pelvic cavity growth several years after the linear growth is complete, resulting in impaired completion of optimal growth in the mother so that nutritional input not sufficient to meet his needs and for the baby's growth.
Growth during adolescence is not optimal due to pregnancy at an early age which affects the nutritional status of the mother and results in stunted fetal growth resulting in low birth weight or a shorter gestational age so that the baby is born prematurely. Babies who do not grow optimally because of unfulfilled intake then affect growth in the later age period. In other words, impaired child growth is the final result of the mother's nutritional status which has a positive effect on the growth of the child in the womb [14]. Pregnancy that occurs during adolescence, when the process of biological and psychological maturation has not been completed, will have a negative impact on the newborn [11]. The history of the mother's nutritional status is an important factor in fetal growth and development. If there is a lack of nutritional status at the beginning of life, it will have an impact on the next life such as Intrauterine growth restriction (IUGR), low birth weight (LBW), small, short and thin, low endurance and the risk of death.

Growth is a continuous process from conception to adulthood. It is proven that the anthropometry of children who have growth problems (stunting) during the intra-uterine and extra-uterine periods is lower than that of children who do not experience growth problems (non-stunting) [12]. This proves that growth is a cycle that will continue. The results in this study indicate that the path coefficient test results show that the health of the newborn, which is influenced by the nutritional status of the mother, also affects the growth of the child. The path coefficient test results showed that the health of newborns had a significant effect on children's growth based on the Tstatistic value above the rule of thumb (>1.96), namely 2.136. Newborn health, which is reflected by birth weight and birth length, is an important indicator that 
can affect a child's growth. Body weight $<2500$ grams has the potential to suffer from a malnutrition and even bad status that affects life, including the risk of growth problems [13]. The pregnancy at an early age causes smaller birth length, preterm birth, other neonatal problems that adversely affect the health of the baby including stunting in childhood [8]. Infants with low birth weight are at risk of experiencing slower growth and development due to brain maturity, problems in the body system due to an unstable state that makes the baby prone to infection. Other problems that may occur such as not getting exclusive breastfeeding are affected by the condition of the baby who is weak and cannot suckle. This will be exacerbated by the low knowledge of mothers regarding the care of babies with low birth weight. These problems have the potential to hinder children's growth.

The effect of a history of nutritional status on children's growth has a positive but not significant effect with the T-statistic value under the rule of thumb $(<1.96)$, namely 0.124 . Maternal nutritional status based on body mass index indicators has a positive relationship with infant weight gain at 1 year of age [7]. Conceptually, the nutritional status of the mother affects milk production which in turn affects the duration of breastfeeding. Problems with breast milk and low knowledge of mothers can affect mothers to provide complementary foods earlier. This study provides further evidence that mothers should initiate pregnancy with appropriate nutrition to optimize exclusive breastfeeding and that mothers should introduce complementary foods at the right time.

Based on the description above, the nutritional status of young pregnant women, the health of newborns, which have a positive and significant impact on children's growth is a challenge for Kupang. This is because the growth problem in childhood are linked to subsequent child development and productivity and become a risk factor for growth problems from generation to generation. Several initiatives and programs such as Adolescent Reproductive Health Care (PKPR) and Generation Plans (Genre) with the aim of preventing early pregnancy have been rolled out but need to be implemented optimally because they help break the cycle of growth problems between generations.

\section{REFERENCES}

1. Goli, S., Rammohan, A., \& Singh, D. (2015). The Effect of Early Marriages and Early Childbearing on Women's Nutritional Status in India. Matern. Child Health J. 19, 1864-1880. Tersedia dari:https://pubmed.ncbi.nlm.nih.gov/25656721/

2. Kemenkes, R. I. (2018). Laporan Nasional Riset Kesehatan Dasar. Kementeri. Kesehat. RI 1-582. Tersedia dari: https://www.litbang.kemkes.go.id/laporan-risetkesehatan-dasar-riskesdas.
3. Dinkes. Profil Kesehatan Kota Kupang. (2018). 19-21. Tersedia dari: https://www.dinkeskotakupang.web.id.

4. Warsini, K. T., Hadi, H., \& Nurdiati, D. S. (2016). Riwayat KEK dan anemia pada ibu hamil tidak berhubungan dengan kejadian stunting pada anak usia 6-23 bulan di Kecamatan Sedayu, Bantul, Yogyakarta. Indonesian J. Nutr. Diet. 4, 29. Tersedia dari: https://ejournal.almaata.ac.id/index.php/IJND/artic le/view/326/297

5. Fadlyana, E., \& Larasaty, S. (2016). Pernikahan Usia Dini dan Permasalahannya. Sari Pediatr. 11, 136. Tersedia dari: https://saripediatri.org/index.php/saripediatri/article/view/607

6. Henseler, J. (2018). Partial least squares path modeling: Quo vadis? Quality and Quantity, 52. Tersedia dari: https://link.springer.com/book/10.1007\%2F978-3540-32827-8

7. Baker, J. L., Michaelsen, K. F., Rasmussen, K. M., \& Sørensen, T. I. A. (2004). Maternal prepregnant body mass index, duration of breastfeeding, and timing of complementary food introduction are associated with infant weight gain. Am. J. Clin. Nutr. 80, 1579-1588. Tersedia dari: https://www.researchgate.net/publication/8141806 _Maternal_Prepregnant_Body_Mass_Index_Durat ion_of_Breastfeeding_and_Timing_of_Compleme ntary_Food_Introduction_are_Associated_with_In fant_Weight_Gain

8. Workicho, A., Belachew, T., Argaw, A., Ghosh, S., Kershaw, M., Lachat, C., \& Kolsteren, P. (2019). Adolescent pregnancy and linear growth of infants: a birth cohort study in rural Ethiopia. Nutrition journal, 18(1), 22.

9. Chen, Y. J., Li, C. R., Lee, S. H., Hsu, B. Q., Wu, W. Y., Kuo, C. P., ... \& Lee, M. C. (2014). Growth changes in infants born of adolescent mothers: Results of a national cohort study in Taiwan. Iranian Journal of Reproductive Medicine, 12(11), 737-746.

10. Prakash, R., Singh, A., Pathak, P. K., \& Parasuraman, S. (2011). Early marriage, poor reproductive health status of mother and child well-being in India. J. Fam. Plan. Reprod. Heal. Care, 37, 136-145. Tersedia dari: https://pubmed.ncbi.nlm.nih.gov/21628349/

11. Baş, E. K., Bülbül, A., Uslu, S., Baş, V., Elitok, G. K., \& Zubarioğlu, U. (2020). Maternal Characteristics and Obstetric and Neonatal Outcomes of Singleton Pregnancies Among Adolescents. Medical Science Monitor: International Medical Journal of Experimental and Clinical Research, 26, e919922-1.

12. Lada, C. O. (2019). Comparing The Anthropometric Measurements of Intra-Extra Uterine Period between Stunting and Non-stunting Children Aged 6-24 Months Old in Bogor Tengah 
Subdistrict, Bogor City, West Java. World Nutr. J. 3, $1 . \quad$ Tersedia dari: http://worldnutrijournal.org/OJS/index.php/WNJ/a rticle/view/V03.i1.0002

13. Zaif, R. M., Wijaya, M., \& Hilmanto, D. (2017). Hubungan antara Riwayat Status Gizi Ibu Masa Keha milan dengan Pertumbuhan Anak Balita di Kecamatan Soreang Kabupaten Bandung. J. Sist. Kesehat. 2, 156-163. Tersedia dari: http://jurnal.unpad.ac.id/jsk_ikm/article/view/1196 4

14. Depertemen Gizi dan Kesehatan Masyarakat, FKM UI. (2010). Gizi dan Kesehatan Masyarakat. Jakarta: Raja Grafindo Persada.

15. Ghozali, I dan Latan, H. (2015). Partial Least Square konsep, teknik dan aplikasi. Badan penerbit-Undip. 